\title{
The Performance Analysis of the Thyroid Nodule Size to Predict the Coexistence of Micropapillary Carcinoma
}

\author{
Mikropapiller Karsinom Birlikteliğini Tahmin Etmek; Tiroid Nodül \\ Boyutu Performans Analizi
}

\author{
(D) Nadir Adnan Hacım¹, (D) Gülçin Ercan¹, (D) Yiğit Ülgen², (D) Talar Vartanoğlu Aktokmakyan¹, \\ (D) Merve Tokoçin11, (D) Serhat Meriç1, (D) Marko Velimirovic33, (D) Candaş Erçetin1, (D) Ahmet Akbaş1, \\ (D) Yüksel Altınel 1
}

${ }^{1}$ University of Health Sciences Turkey, İstanbul Bağcılar Training and Research Hospital, Clinic of General Surgery, İstanbul, Turkey

2University of Health Sciences Turkey, İstanbul Bağcllar Training and Research Hospital, Clinic of Pathology, İstanbul, Turkey

3Massachusetts General Hospital, Harvard Medical School, Department of Medicine, Boston, USA

\section{Abstract}

Objective: Incidental micropapillary carcinoma (IMC) is the most common variant of thyroid malignancies. There are unmet needs regarding the efficacy of nodule size in the prediction of the coexistence of IMC. We aimed to measure the effect of nodule size on the prediction of the coexistence of IMC.

Method: The data of 194 patients who underwent biopsy for fine-needle aspiration cytology and subsequent thyroidectomy in a research and training hospital between January 2017 and February 2020 were analyzed retrospectively. The patients were divided into three groups according to the sizes of thyroid nodules as 0-10 mm, 11-20 mm, and >20 mm. Logistic regression analysis was performed.

Results: The patients with nodule size between $0 \mathrm{~mm}$ and $10 \mathrm{~mm}$ mostly showed hypothyroidism ( $51.0 \%$ vs. $28.8 \%$ vs. $41.8 \%$ ) while patients with size between $11 \mathrm{~mm}$ and $20 \mathrm{~mm}$ mostly had euthyroidism (44.2\% vs. 45.1\% vs. $41.8 \%, p=0.0175)$. Both malignancy ( $51.9 \%$ vs. $49.0 \%$ vs. $42.9 \%, p=0.544)$ and IMC $(65.4 \%$ vs. $51.0 \%$ vs. $56.0 \%, p=0.32)$ were observed more likely in patients with moderate size (11-20 mm). We found the following variables to be predictors for the coexistence of IMC: absence of halo [odds ratio (OR): 4.50, 95\% confidence interval (Cl): 1.61-14.71, $\mathrm{p}=0.007$, and interestingly decrease in vascularity [OR: $0.33,95 \% \mathrm{Cl}: 0.12-0.87, \mathrm{p}=0.030$ ], and total thyroidectomy, [OR: 4.55, 95\% $\mathrm{Cl}: 2.30-9.56, \mathrm{p}<0.001]$.

Conclusion: With increased nodule size $(>2 \mathrm{~cm})$, we reported more IMC inside the thyroid gland. However, the nodule size has the low performance to be a predictor for the coexistence of IMC in the thyroid gland.

Keywords: Malignancy, nodule size, thyroidectomy

\section{Öz}

Amaç: İnsidental mikropapiller karsinom (IMK), tiroid malignitelerinin en yaygın mikropapiller varyantıdır ve son on yılda insidansı artmaktadır. Tiroid bezinde IMK varlığını tahmin etmede nodül boyutunun etkinliğine iliş̧in veriler yeterli değildir. Bu retrospektif çalışmada nodül boyutunun, IMK'lerin tiroid bezinde diğer lezyonlarla bir arada bulunmasının öngörülmesine etkisini araştırdık.

Yöntem: Ocak 2017- Şubat 2020 tarihleri arasında ince iğne aspirasyon sitolojisi ve ardından tiroidektomi için biyopsi yapılan 194 hastanın verileri retrospektif olarak incelendi. Hastalar tiroid nodüllerinin boyutlarına göre 0-10 mm, 11-20 mm ve >20 mm olarak üç gruba ayrıldı.

Bulgular: Nodül boyutu $0-10 \mathrm{~mm}$ arasında olan hastalarda en çok hipotiroidizm (\%51,0, \%28,8 ve \%41,8) görülürken, boyutu $11-20 \mathrm{~mm}$ arasındaki hastalarda en çok ötiroidizm görüldü (\%44,2, \%45,1 ve \%41,8, $\mathrm{p}=0,0175)$. Hem malignitenin $(\% 51,9, \% 49,0$ ve $\% 42,9, p=0,544)$ hem de iMK'nin (\%65,4, \%51,0 ve \%56,0, p=0,32), orta büyüklükte $(11-20 \mathrm{~mm})$ nodül boyutu olan hastalarda görülme olasılığı yüksekti. Aşağıdaki değişkenlerin IMK'nin görülmesini daha fazla etkilediğini bulduk: halo yokluğu [olasılık oranı (OO): 4,50, \%95 güven aralı̆̆ı (GA): 1,61-14,71, $p=0,007$, vasküleritede azalma [OO: 0,33, \%95 GA: 0,12-0,87, $p=0,030$ ] ve total tiroidektomi [OO: 4,55, \%95 GA: 2,30-9,56, $p<0,001]$.

Sonuç: Nodül boyutunda artışla $(>2 \mathrm{~cm}$ ) birlikte tiroid bezi içinde daha fazla IMK'ye rastlanmıştır. Bununla birlikte, nodül boyutunun tiroid bezinde iMK bulunma riski için prediktif bir faktör olma potansiyeli düşüktür.

Anahtar kelimeler: Malignite, nodül boyutu, tiroidektomi

Address for Correspondence: Adnan Hacım, University of Health Sciences Turkey, İstanbul Bağcılar Training and Research Hospital, Clinic of General Surgery, İstanbul, Turkey

E-mail: adnanhcm@hotmail.com ORCID: orcid.org/0000-0002-3906-2538 Received: 05.02.2021 Accepted: 02.06.2021

Cite this article as: Hacım NA, Ercan G, Ülgen Y, Vartanoğlu Aktokmakyan T, Tokoçin M, Meriç S, Velimirovic M, Erçetin C, Akbaş A, Altınel Y. The Performance Analysis of the Thyroid Nodule Size to Predict the Coexistence of Micropapillary Carcinoma. 


\section{Introduction}

Thyroid nodules are typically benign lesions with a prevalence of $2-6 \%$ with palpation, $19-35 \%$ with routine ultrasound imaging (USG), and 8-65\% in biopsy (1). The incidental malignant tumors of the thyroid gland can be detected by post-operative examination because of benign lesions. Additionally, incidental thyroid carcinoma is the most common pathological type with an incidence ranging from $3 \%$ to $20.3 \%(2,3)$. Incidental micropapillary carcinoma (IMC) is the most common micropapillary variant (3), with an increasing incidence in the past decades, due to developments and much use of diagnostic procedures, which enable the detection of smaller tumors, particularly IMC in the nodules of a diameter smaller than $10 \mathrm{~mm}$ according to the World Health Organization classification system (4). It is controversial whether or not the size of the thyroid nodule is correlated with the presence of IMC and other clinicopathological features of patients $(5,6)$. Despite the fact that the prognostic advantage of IMCs has been an issue of debate in recent studies (6-8), there is a lack of information about the predictive value of the size of thyroid nodules in the risk and early diagnosis of IMC among thyroid cancers (911). Although most IMCs were discovered incidentally on Fine Needle Aspiration Cytology (FNAC) during the pathological examination of benign lesions, there are unmet needs regarding the efficacy of nodule size in the prediction of the presence of IMCs in the thyroid gland. We investigated the effect of the nodule size on the prediction of the association of IMCs in the thyroid gland with ultrasonographical non-visualized adjacent malignancies. Our retrospective study is a good clinical tool to consider the nodule size as a predictive factor for the presence of IMC in the thyroid gland. It is important to consider the thyroid nodule size during outpatient follow-up to suspect the further association of IMC in the thyroid gland.

\section{Materials and Methods}

A retrospective review of the data of 194 patients who underwent FNA biopsy and subsequent thyroidectomy in the General Surgery Department of University of Health Sciences Turkey, İstanbul Bağcılar Training and Research Hospital between January 2017 and February 2020 was performed. This study was approved by the Clinical Research Ethics Committee of University of Health Sciences Turkey, İstanbul Bağcllar Training and Research Hospital (no: 2020.02.1.03.021, date: 07/02/2020). All procedures were inconsistent with the principles of the Helsinki Declaration. The patient consent could not be received from the patients due to the retrospective design of the study.

\section{Patients}

The selection criteria of the patients were based on the FNA biopsy and subsequent thyroidectomy, including all data of demographics and clinical features. The patients with incomplete data were excluded from the study. The data of patients including the demographic features were about sex, age, radiation history, family history of thyroid diseases, type of surgery, and the diameter of the nodule $(\mathrm{mm})$. As clinical indications, FNA, nodule size, compression/ cosmetics, Grave's disease, toxic goiter, and coexisting hyperparathyroidism were recorded. The diagnoses with thyroid function tests, including hypothyroidism, euthyroidism, or hyperthyroidism, were recorded. Lymphadenectomy was performed as central, regional, or central with regional levels. FNA cytology (FNAC) findings were determined by the Bethesda category, and an overall histopathological diagnosis (benign or malign) was recorded according to the pathology reports. All data were analyzed by comparing the outcomes with the nodule size and IMC. The sizes of thyroid nodules were determined according to the recent ATA guidelines and the patients were divided accordingly into three groups as $0-10 \mathrm{~mm}, 11-20 \mathrm{~mm}$, and $>20 \mathrm{~mm}$ (12). IMC was determined as a well-differentiated single tumor or multiple tumors smaller than $1 \mathrm{~cm}$, diagnosed incidentally in intra or extra-nodular region, inside or outside the same lobe with a benign or malign lesion. IMC was also confirmed by immunohistochemically positive staining for thyroglobulin, showing a follicular differentiation. We included IMC in intra-nodular region and inside the same lobe with a benign or malign lesion.

\section{USG}

Ultrasound (US) imaging of the thyroid was performed by the Esaote Color Doppler US (MAG Technology Co, Ltd. Model: 796FDII Yung-ho City, Taipei, Taiwan). Radiological findings recorded for each nodule included the echogenicity (hypoechoic or hyper- and isoechoic), margin (irregular or well-bordered), microcalcifications (absent or present), the peripheral halo (absent or present), increased vascularity (absent or present), and cervical lymph nodes (13).

\section{FNAC}

All cytological and pathological examinations of thyroid samples were performed by an experienced cytopathologist. FNA biopsy was performed by the guidance of General 
Electric Logiq pro 200 US (Model number 2270968; GE Healthcare Korea, Seongnam SI, Gyean GGI-DO, Korea). The aspiration samples were evaluated by May-GrunwaldGiemsa for cytological examination. The Bethesda System for Reporting Thyroid Cytopathology system was used to analyze FNAC samples described in the literature (14).

\section{Statistical Analysis}

The categorical variables were reported as percentages and also continuous variables as mean with standard deviation for descriptive statistics. The chi-square test for categorical variables and t-test for continuous variables were performed by univariate analysis comparing patients with the coexistence of IMC. The dataset was diverged arbitrarily into two cohorts: $75 \%$ of patients were used in a training set, and the remaining $25 \%$ were used as a test set. A clinically applicable prediction model for the coexistence of IMC was created by a selection-based analysis ( $\mathrm{p}<0.05$ in univariate analyses of the unadjusted covariates based on the per-operative assessment). The determination of predictive variables for the coexistence of IMC to control potential confounders was utilized by multivariable logistic regression. The test set identified the sensitivity, specificity and receiver-operating characteristic curve (receiver operating characteristic curve) of each model. The bootstrapping to generate a $95 \%$ confidence interval of the sensitivity and specificity was performed. Significance was the level of $p<0.05$. $R$ software version 3.4.2. was used for analysis.

\section{Results}

\section{Outcomes Regarding Nodule Size}

A comparison of patient characteristics based on the increase in nodule size was evaluated. (Table 1). The total number of patients was $194,75.3 \%$ of these patients were female, and $24.7 \%$ were male. The mean age of all patients was $46.6 \pm 13.1$ years (18-89 years). Only one patient having a nodule size larger than $20 \mathrm{~mm}(0.52 \%)$ had radiation therapy on the neck, and three patients $(1.55 \%)$ had a family history of thyroid carcinoma. The mean diameter of nodules was found as $22.2 \pm 14.8 \mathrm{~mm}$. Euthyroidism was diagnosed in 84 patients (43.3\%). Hyperthyroidism was the rarest status of thyroid function among all patients (15.5\%). The patients with nodule size between $0 \mathrm{~mm}$ and $10 \mathrm{~mm}$ mostly showed hypothyroidism ( $51.0 \%$ vs. $28.8 \%$ vs. $41.8 \%$, $\mathrm{p}=0.0175)$ while patients with size between $11 \mathrm{~mm}$ and 20 $\mathrm{mm}$ mostly had euthyroidism $(44.2 \%$ vs. $45.1 \%$ vs. $41.8 \%$, $\mathrm{p}=0.0175)$. The ratio of overall benign pathology $(53.1 \%)$ was higher than that of malignancies (46.9\%) among all patients. Lastly, $57.2 \%$ of all patients were diagnosed as IMC, without any difference among the groups. Both a malignancy $(49.0 \%$ vs. $51.9 \%$ vs. $42.9 \%, \mathrm{p}=0.544)$ and IMC ( $51.0 \%$ vs. $65.4 \%$ vs. $56.0 \%, \mathrm{p}=0.32$ ) were observed more likely in the patients with a moderate nodule size (11-20 $\mathrm{mm})$. Especially, malignancy was observed in the nodules less than $2 \mathrm{~cm}$ (Table 1, 2).

\section{Outcomes Regarding IMC}

We reported, based on univariate regression (Table 3), that thyroid function status (euthyroidism, hyperthyroidism), absence of halo, and total thyroidectomy in the peroperative features emerged to be associated with the coexistence of IMC. Increase in nodule size did not seem to predict eventual coexistence of IMC [odds ratio (OR): 1.066, 95\% confidence interval (CI): 0.757-1.501, $\mathrm{p}=0.712$ ], (Table 2).

In our latest multivariable prediction model, there were 6 variables, which were identified according to either they were statistically significant on the univariate analysis or they had been formerly mentioned in the literature as potential predictors for the coexistence of IMC: thyroid function status (euthyroidism, hyperthyroidism), radiological absence of halo radiological vascularity, and surgery (total thyroidectomy), overall malignant pathology and pathological differentiation (nodular goiter, etc.). Briefly, we reported some of the findings to be a predictor for the coexistence of IMC: absence of halo (OR: 4.5095\% CI: 1.61-14.71, $\mathrm{p}=0.007$ ), and interestingly decrease in vascularity (OR: $0.33,95 \% \mathrm{CI}: 0.12-0.87, \mathrm{p}=0.030$ ), and total thyroidectomy, (OR: 4.55, 95\% CI: 2.30-9.56, p<0.001), (Figure 1).

The area under curve of the test set was $(0.72,95 \%$ CI: 0.61 0.78 ), sensitivity and specificity were 0.56 (95\% CI: 0.38 0.72 ) and 0.79 (95\% CI: 0.64-0.92), respectively (Figure 2). Our model was pretty good at detecting the true negatives of IMC, but average at detecting true positives of IMC.

\section{Discussion}

Thyroid nodules are clinically indicated for thyroid dysfunction and compressive symptoms; however, they are mostly critical in the diagnosis of thyroid malignancies. The ratio of malignancy in thyroid nodules diagnosed by biopsy has been reported between $4.0 \%$ and $6.5 \%$ and generally unconventional of the nodule size $(15,16)$. However, IMCs which are incidentally diagnosed at the time of thyroidectomy are much more common than the 
overall malignancies (up to 36\%) (17). Consistent with our findings, malignancy was observed at the rate of $36 \%$ in patients with IMC $(\mathrm{p}=0.0008)$. Although the prognostics of IMC are controversial, early diagnosis and treatment of IMC are still crucial since the small size alone does not lower the risk of incidental thyroid malignancies $(3,6,18,19)$. Consistent with our study, overall malignancy was reported more likely in the nodules less than $2 \mathrm{~cm}$ ( $49 \%$ vs. $51.9 \%$ vs. $42.9 \%, \mathrm{p}=0.544$ ). Additionally, the diameter of nodule size has no impact to induce the coexistence of IMC (51\% vs. $65.4 \%$ vs. $56 \%, \mathrm{p}=0.32$ ). Since this risk of malignancy is high, such nodules including IMCs require urgent examination and diagnosis. Therefore, we investigated the effect of the nodule size on the prediction of the association of IMCs in patients' pathological specimen with ultrasonographical non-visualized adjacent malignancies. We found that an increase in nodule size did not seem to predict the eventual coexistence of IMC (OR: 1.066, 95\% CI: 0.757- 1.501, $\mathrm{p}=0.712)$.

In current literature, it was shown that high TSH level prior to surgery was shown with a higher risk of differentiated

\begin{tabular}{|c|c|c|c|c|c|}
\hline & \multirow{2}{*}{$\begin{array}{l}\text { Total } \\
n=194\end{array}$} & \multicolumn{3}{|c|}{ Nodule size } & \multirow[t]{2}{*}{$\mathbf{p}$} \\
\hline & & $\begin{array}{l}0-10 \mathrm{~mm} \\
\mathrm{n}=51\end{array}$ & $\begin{array}{l}11-20 \mathrm{~mm} \\
\mathrm{n}=52\end{array}$ & $\begin{array}{l}>20 \mathrm{~mm} \\
\mathrm{n}=91\end{array}$ & \\
\hline Female & $146(75.3)$ & $44(86.3)$ & $39(75)$ & $63(69.2)$ & 0.078 \\
\hline Male & $48(24.7)$ & $7(13.7)$ & $13(25)$ & $28(30.8)$ & \\
\hline n (\%) & $1(0.52)$ & $0(0)$ & $0(0)$ & $1(1.1)$ & 0.566 \\
\hline n (\%) & $3(1.55)$ & $0(0)$ & $0(0)$ & $3(3.3)$ & 0.178 \\
\hline Hypothyroidism & $78(40.2)$ & $26(51.0)$ & $15(28.8)$ & $38(41.8)$ & 0.0175 \\
\hline Euthyroidism & $84(43.3)$ & $23(45.1)$ & $23(44.2)$ & $38(41.8)$ & \\
\hline Min-max & $(3-70)$ & $(3-10)$ & $(11-20)$ & $(21-70)$ & \\
\hline Hypo echogenicity & $119(61.3)$ & $38(74.5)$ & $33(63.5)$ & $49(53.8)$ & - \\
\hline Irregular margin & $47(24.2)$ & $19(37.3)$ & $7(13.5)$ & $21(23.1)$ & - \\
\hline Microcalcifications & $51(26.3)$ & $19(37.3)$ & $10(19.2)$ & $22(24.2)$ & 0.214 \\
\hline Loss of halo & $29(14.9)$ & $8(15.7)$ & $6(11.5)$ & $15(16.5)$ & - \\
\hline Increased vascularity & $26(13.4)$ & $4(7.8)$ & $5(9.6)$ & $17(18.7)$ & - \\
\hline Cervical lymph nodes & $73(37.6)$ & $24(47.1)$ & $23(44.2)$ & $26(28.6)$ & - \\
\hline Toxic nodular goiter & $43(22.1)$ & $6(11.8)$ & $10(19.2)$ & $27(29.7)$ & 0.058 \\
\hline MNG & $60(30.9)$ & $20(39.2)$ & $15(28.8)$ & $25(27.5)$ & - \\
\hline Cancer suspicious & $58(29.9)$ & $15(29.4)$ & $22(42.3)$ & $21(23.1)$ & \\
\hline Cancer & $28(14.4)$ & $9(17.6)$ & $7(13.5)$ & $12(13.2)$ & \\
\hline Benign & $103(53.1)$ & $26(51.0)$ & $25(48.1)$ & $52(57.1)$ & 0.544 \\
\hline Malign & $91(46.9)$ & $25(49.0)$ & $27(51.9)$ & $39(42.9)$ & \\
\hline n (\%) & $111(57.2)$ & $26(51.0)$ & $34(65.4)$ & $51(56.0)$ & 0.320 \\
\hline
\end{tabular}

SD: Standard deviation, FNAC: Fine needle aspiration cytology, AUS/FLUS: Atypia of undetermined significance or follicular lesion of undetermined significance, IMC: Incidental micropapillary carcinoma 
thyroid carcinoma while hyperfunctioning was not considered as a protective factor. Also, incidental thyroid carcinoma is found to be more in euthyroid patients. $(4,20)$. We reported that the patients diagnosed with IMC more likely showed euthyroidism, suggesting that the preoperative status of thyroid function might induce the

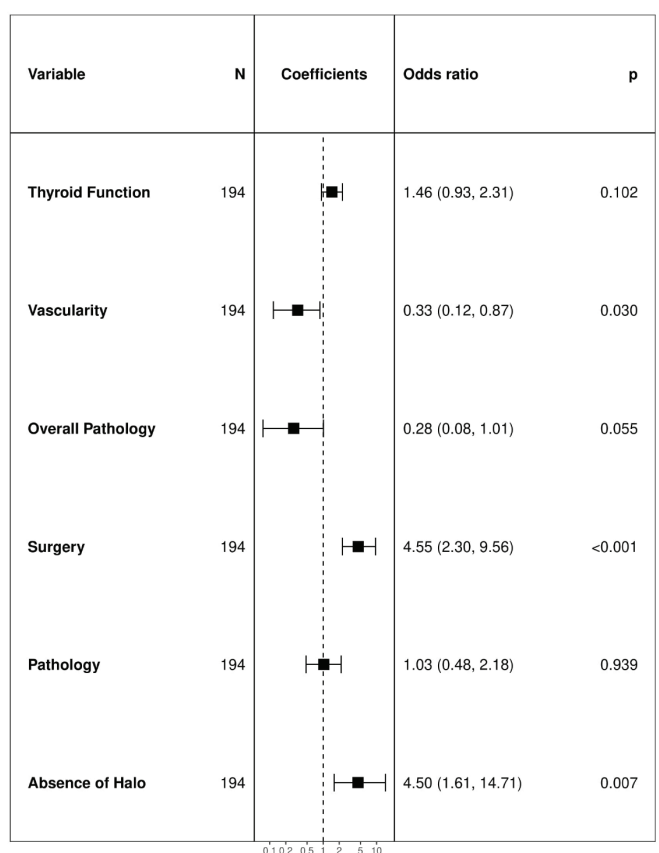

Figure 1. Adjusted covariates for the coexistance of incidental micropapillary carcinoma

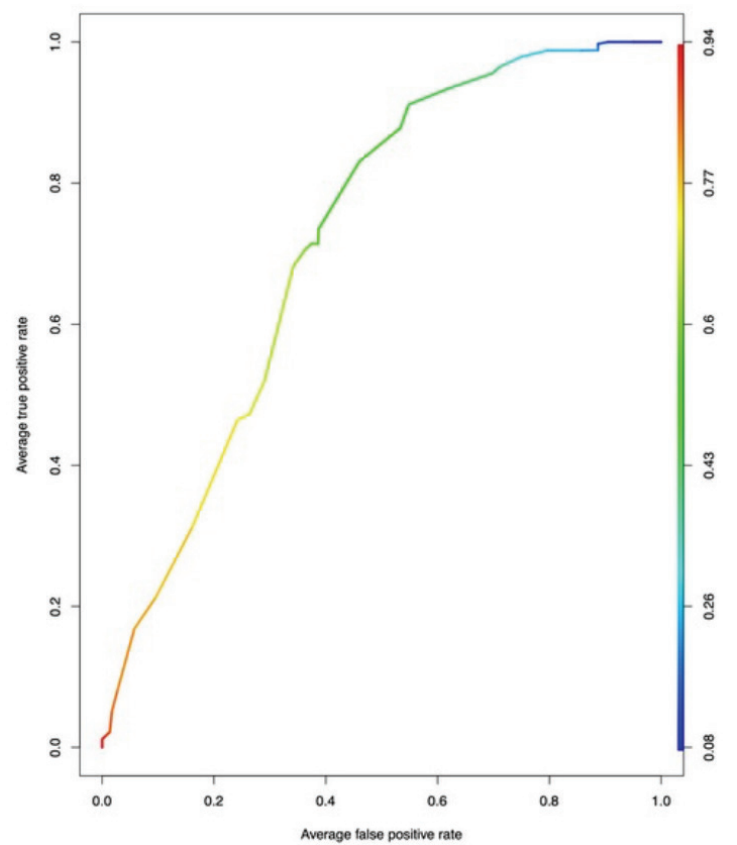

Figure 2. Prediction model of incidental micropapillary carcinoma coexistence of IMC in the thyroid gland.

It might be considered that TSH concentration is promptly related to the size of the malignant nodule, regardless of the other kind of nodule. Furthermore, TSH concentrations were found to be increased with differentiated thyroid carcinoma inside the dominant nodule in these patients compared to those with a benign dominant nodule $(4,20)$. Consistently, we found that the nodule size between $0 \mathrm{~mm}$ and $10 \mathrm{~mm}$ was mostly indicative of hypothyroidism while the size between $11 \mathrm{~mm}$ and $20 \mathrm{~mm}$ was mostly indicative of euthyroidism. The nodule size larger than $20 \mathrm{~mm}$ showed similar rates of hypothyroidism and euthyroidism among patients. The rates of hyperthyroidism among patients with middle and large size nodules were significantly larger than those among patients with a smaller size, suggesting that TSH concentrations might be correlated with the coexistence of IMC regarding the increase in nodule size.

In some studies, it has been reported that nodule size has a low potential impact on the presence of malignancy regardless of the diameter such as a nodule smaller than 1 $\mathrm{cm}$ or larger in the presence of doubtful ultrasonographic findings (21). Small nodules are suggested to be biopsied only if there is more than one suspicious ultrasonographic feature, extracapsular growth, abnormal cervical lymph nodes, or high-risk history. Likewise, a diameter of $1 \mathrm{~cm}$ can be utilized for solid nodules that have only one doubtful ultrasonographic finding, such as microcalcifications or hypo echogenicity (22), which is consistent with our findings including irregular margins in the nodule size less than 1 $\mathrm{cm}$. In addition, we especially reported a correlation with the coexistence of IMC between the decreased vascularity (OR: 0.33, 95\% CI: 0.12-0.87, $\mathrm{p}=0.030$ ) and loss of halo (OR: $4.50,95 \%$ CI: 1.61-14.71, $\mathrm{p}=0.007$ ) in thyroid tissue.

There are various controversies about the nodule size, as a variable for predicting malignancy, and the management of treatment. Currently, Al-Hakami et al. (23) reported that the majority of malignancy risk was found in nodules less than $2 \mathrm{~cm}$ in contrast to nodules larger than $2 \mathrm{~cm}$. The baseline cancer risk of $64.8 \%$ was observed in the thyroid nodules diameter of $1.0-1.9 \mathrm{~cm}$. The general ratio of malignancy in nodules larger than $2 \mathrm{~cm}$ were $17.6 \%, 10.6 \%$, and $7 \%$ (nodules $4.0 \mathrm{~cm}$ ) (20). In the present study, we divided the nodule sizes into three groups as $0-1.0 \mathrm{~cm}, 1.1-2.0 \mathrm{~cm}$, and the size larger than $2 \mathrm{~cm}$. The patients with medium-sized nodules $(1.1-2.0 \mathrm{~cm})$ showed more malignancy in overall pathology while the patients with smaller and larger sizes showed more likely benign pathology. 
Table 2. Demographic and clinical features of the patients in comparison to the presence of IMC

\begin{tabular}{|c|c|c|c|c|c|}
\hline \multirow[t]{2}{*}{ Variables } & & \multirow{2}{*}{$\begin{array}{l}\text { Total } \\
n=194\end{array}$} & \multicolumn{2}{|l|}{ IMC } & \multirow[t]{2}{*}{$\mathbf{p}$} \\
\hline & & & $\begin{array}{l}\text { Absent } \\
n=83\end{array}$ & $\begin{array}{l}\text { Present } \\
n=111\end{array}$ & \\
\hline Sex, n (\%) & Male & $48(24.7)$ & $23(27.7)$ & $25(22.5)$ & \\
\hline Age (year) & Mean \pm SD & $46.6 \pm 13.1$ & $45.6 \pm 13.2$ & $47.4 \pm 13.0$ & 0.343 \\
\hline \multirow{2}{*}{ Status of thyroid function $\mathrm{n}(\%)$} & Euthyroidism & $84(43.3)$ & $33(39.8)$ & $51(45.9)$ & \\
\hline & Hyperthyroidism & $30(15.5)$ & $9(10.8)$ & $21(18.9)$ & \\
\hline Type of surgery & Lobectomy & $19(9.8)$ & $15(18.1)$ & $4(3.6)$ & 0.0019 \\
\hline n (\%) & Total thyroidectomy & $175(90.2)$ & $68(81.9)$ & $107(96.4)$ & \\
\hline & Microcalcifications & $51(26.3)$ & $25(30.1)$ & $26(23.4)$ & 0.356 \\
\hline & Loss of Halo & $29(14.9)$ & $7(8.4)$ & $22(19.8)$ & - \\
\hline & Increased vascularity & $26(13.4)$ & $13(15.7)$ & $13(11.7)$ & - \\
\hline & Cervical lymph nodes & $73(37.6)$ & $32(38.6)$ & $41(36.9)$ & - \\
\hline FNAC findings & Nondiagnostic/insufficient & $20(10.3)$ & $7(8.4)$ & $13(11.7)$ & 0.598 \\
\hline \multirow[t]{4}{*}{ n (\%) } & Benign & $34(17.5)$ & $13(15.7)$ & $21(18.9)$ & \\
\hline & AUS/FLUS & $41(21.1)$ & $17(20.5)$ & $24(21.6)$ & \\
\hline & Follicular neoplasm & $12(6.2)$ & $3(3.6)$ & $9(8.1)$ & \\
\hline & Cancer suspicious & $58(29.9)$ & $28(33.7)$ & $30(27.0)$ & \\
\hline
\end{tabular}

SD: Standard deviation, FNAC: Fine needle aspiration cytology, AUS/FLUS: Atypia of undetermined significance or follicular lesion of undetermined significance, IMC: Incidental micropapillary carcinoma

In the present study, the incidence of IMC was higher among the patients with nodule size between $1.1 \mathrm{~cm}$ and $2.0 \mathrm{~cm}$ but no significance was shown between the groups regarding the coexistence of IMC. Al-Hakami et al. (23) demonstrated that the nodular size of $1.0-1.9 \mathrm{~cm}$ was primarily contained in the papillary carcinoma, likewise Kamran et al. (24) observed that increasing nodule size had a contrary correlation with a papillary carcinoma, which is similar to our findings ( $49 \%$ vs. $46.2 \%$ vs. $35.2 \%$, $\mathrm{p}=0.124$ ). Contrary to our findings, El-Gammal et al. (25) have shown that larger nodule sizes over $2 \mathrm{~cm}$ have more papillary carcinomas. Therefore, we observed that the size of the nodule had a low potential to be a predictive factor for the coexistence of IMC in the thyroid gland ( $\mathrm{p}=0.712$ ).

\section{Study Limitations}

The limitations in our study were that small sample size was analyzed from the data of a single center and thyroid surgery group was from a restricted region, which may limit the generalization to other regions and groups. Secondly, our study was limited by its retrospective analysis including measurement, observation, and recall biases. Also, no stepwise or any other machine learning models were further used to measure the performance of our prediction model.

\section{Conclusion}

Despite these limitations, this study is a clinically valuable diagnostic tool showing that the nodule size might be a good predictor for the coexistence of IMC in the thyroid gland regarding the absence of halo and vascularity. Another strength of the study was the outcome that the patients diagnosed with IMC more likely had euthyroidism or hyperthyroidism and were observed mostly in total thyroidectomy specimens. However, there are still debates 
Table 3. Unadjusted covariates of patients based on the coexistance of incidental micropapillary carcinoma

\begin{tabular}{llll} 
& OR & $\mathbf{9 5 \%} \mathbf{C l}$ & $\mathbf{p}$ \\
\hline Age & 1.010 & $0.988-1.033$ & 0.340 \\
Thyroid function & 1.616 & $1.063-2.456$ & $0.024^{*}$ \\
Surgery & 5.900 & $1.879-18.525$ & $0.002^{*}$ \\
Hypo echogenicity & 0.942 & $0.524-1.694$ & 0.844 \\
Irregular margin & 1.012 & $0.521-1.967$ & 0.970 \\
Increased vascularity & 0.714 & $0.312-1.634$ & $0.042^{*}$ \\
Microcalcifications & 1.355 & $0.583-3.144$ & 0.479 \\
Loss of halo & 2.683 & $1.086-6.627$ & $0.032^{*}$ \\
Cervical lymph nodes & 0.933 & $0.519-1.678$ & 0.818 \\
FNAC findings & 0.631 & $0.090-0.885$ & 0.0277 \\
Pathology & 1.866 & $0.997-3.494$ & 0.051 \\
Overall pathology & 0.353 & $0.196-0.636$ & $0.0005^{*}$ \\
Nodule size & 1.066 & $0.757-1.501$ & 0.712 \\
\hline
\end{tabular}

OR: Odds ratio, FNAC: Fine needle aspiration cytology, $\mathrm{Cl}$ : Confidence interval, ${ }^{*}$ p-value $<0.05$

about the pathological assessment of IMC in the thyroid gland. Therefore, defining a cut-off nodule size for the potential coexistence of IMC in a thyroid gland requires studies with large sample size and further clinical trials.

\section{Ethics}

Ethics Committee Approval: The Clinical Research Ethics Committee of University of Health Sciences Turkey, İstanbul Bağcılar Training and Research Hospital approved the study protocol (decree number: 2020.02.1.03.021, date of approval: 07/02/2020). All procedures performed in this study involving human participants were under the ethical standards of the institutional research committee and with the 1964 Helsinki Declaration and its later amendments or comparable ethical standards.

Informed Consent: Patient consent form was not required due to the nature of the study.

Peer-review: Externally peer-reviewed.

\section{Authorship Contributions}

Concept: N.A.H., Y.A., A.A., G.E., Design: N.A.H., Y.A., A.A., G.E., Data Collection or Processing: Y.Ü., T.V.A., M.T., S.M., A.A., Analysis or Interpretation: N.A.H., C.E., G.E., Y.Ü., A.A., Drafting Manuscript: N.A.H., Y.A., M.V., T.V.A., Critical Revision of Manuscript: Y.A., C.E., S.M., M.V., Final Approval and Accountability: N.A.H., S.M., G.E., M.T., Y.A., Technical or Material Support: Y.Ü., G.E., T.V.A., C.E., M.T., Supervision: N.A.H., Y.A., M.V.

Conflict of Interest: No conflict of interest was declared by the authors.
Financial Disclosure: The authors declared that this study received no financial support.

\section{References}

1. Dean DS, Gharib H. Epidemiology of thyroid nodules. Best Pract Res Clin Endocrinol Metab 2008;22(6):901-911.

2. Fink A, Tomlinson G, Freeman JL, Rosen IB, Asa SL. Occult micro-papillary carcinoma associated with benign follicular thyroid disease and untreated thyroid neoplasms. Mod Pallid 1996;9(8):816-820.

3. Nanjappa N, Kumar A, Swain SK, Aroul TT, Smile SR, Kotasthane D. Incidental thyroid carcinoma. Indian J Otolaryngol Head Neck Surg 2013;65(1):37-39.

4. Zalzali M, Debreuve A, Richard C, Filieri C, Schvartz C. Micropapillary carcinoma: Description and rise in incidence in the French Marne-Ardennes thyroid cancer registry. Ann Endocrinol (Paris) 2019;80(4):229-233.

5. Kang KW, Kim SK, Kang HS, Lee ES, Sim JS, Lee IG, et al. Prevalence and risk of cancer of focal thyroid incidentaloma identified by 18F-fluorodeoxyglucose positron emission tomography for metastasis evaluation and cancer screening in healthy subjects. J Clin Endocrinol Metab 2003;88(9):4100-4104.

6. Lyu YJ, Shen F, Yan Y, Situ M, Wu W, Jiang G, et al. Ultrasoundguided fine-needle aspiration biopsy of thyroid nodules $<10 \mathrm{~mm}$ in the maximum diameter: does size matter? Cancer Manag Res 2019;11:1231-1236

7. Gao X, Zhang X, Zhang Y, Hua W, Maimaiti Y, Gao Z. Is papillary thyroid microcarcinoma an indolent tumor?: a retrospective study on 280 cases treated with radioiodine. Medicine (Baltimore) 2016;95(40):e5067. doi: 10.1097/MD.0000000000005067.

8. Yaprak Bayrak B, Eruyar AT. Malignancy rates for Bethesda III and IV thyroid nodules: a retrospective study of the correlation between fine-needle aspiration cytology and histopathology. BMC Endocr Disord 2020;20(1):48.

9. Kim DW, ParkAW, Lee EJ, Choo HJ, Kim SH, LeeSH, et al. Ultrasoundguided fine-needle aspi- ration biopsy of thyroid nodules smaller than $5 \mathrm{~mm}$ in the maximum diameter: assessment of efficacy and pathological findings. Korean J Radiol 2009;10(5):435-440.

10. 10. Rosario PW, Silva AL, Calsolari MR. Is fine needle aspiration really not necessary in patients with thyroid nodules $\leq 1 \mathrm{~cm}$ with highly suspicious features on ultrasonography and candidates for active surveillance? Diagn Cytopathol 2017;45(4):294-296.

11. Zhong LC, Lu F, Ma F, Xu HX, Li DD, Guo LH, et al. Ultrasoundguided fine-needle aspiration of thyroid nodules: does the size limit its efficiency? Int J Clin Exp Pathol 2015;8(3):3155-3159.

12. Haugen BR. 2015 American Thyroid Association management guidelines for adult patients with thyroid nodules and differentiated thyroid cancer: what is new and what has changed? Cancer 2017;123(3):372-381.

13. Wu Q, Li Y, Liu Y, Shen J, Wang Y, YiX, et al. The value of conventional sonography and ultrasound elastography in decision-making for thyroid nodules in different categories of the Bethesda system for reporting thyroid cytopathology. Clin Hemorheol Microcirc 2020;74(3):255- 266.

14. Cibas ES, Ali SZ. The Bethesda system for reporting thyroid cytopathology. Thyroid 2009;19(11):1159-1165. 
15. Hegedus L. Clinical practice. The thyroid nodule. N Engl J Med 2004;351(17):1764-1771.

16. Lin JD, Chao TC, Huang BY, Chen ST, Chang HY, Hsueh C, et al. Thyroid cancer in the thyroid nodules evaluated by ultrasonography and fine-needle aspiration cytology. Thyroid 2005;15(7):708-717.

17. De Matos PS, Ferreira AP, Ward LS. Prevalence of papillary microcarcinoma of the thyroid in Brazilian autopsy and surgical series. Endocr Pathol 2006;17(2):165-173.

18. Nam-Goong IS, Kim HY, Gong G, Lee HK, Hong SJ, Kim WB, et al. Ultrasonography-guided fine needle aspiration of thyroid incidentaloma: correlation with pathological findings. Clin Endocrinol (Oxf) 2004;60(1):21-28.

19. Kim DW, Lee EJ, Kim SH, Kim TH, Lee SH, Kim DH, et al. Ultrasound-guided fine-needle aspiration biopsy of thyroid nodules: comparison in efficacy according to nodule size. Thyroid 2009;19(1):27-31.

20. Zafón C, Obiols G, Mesa J. Preoperative TSH level and risk of thyroid cancer in patients with nodular thyroid disease: nodule size contribution. Endocrinol Nutr 2015;62(1):24-28.
21. Kim EK, Park CS, Chung WY, Oh KK, Kim DL, Lee JT, et al. New sonographic criteria for recommending fine-needle aspiration biopsy of nonpalpable solid nodules of the thyroid. AJR Am J Roentgenol 2002;178(3):687-691.

22. Popoveniuc G, Jonklaas J. Thyroid nodules. Med Clin North Am 2012;96(2):329-349.

23. Al-Hakami HA, Alqahtani R, Alahmadi A, Almutairi D, Algarni M, Alandejani T. Thyroid nodule size and prediction of cancer: a study at tertiary care hospital in Saudi Arabia. Cureus 2020;12(3):e7478. doi: 10.7759 /cureus.7478.

24. Kamran SC, Marqusee E, Kim MI, Frates MC, Ritner J, Peters H, et al. Thyroid nodule size and prediction of cancer. J Clin Endocrinol Metab 2013;98(2):564-570.

25. El-Gammal Ahmed S, E-Balshy Mohammed A, Zahran Kareem M. Relationship between thyroid nodule size and incidence of thyroid cancer. Menoufia Med J 2019; 32(3):1142-1148. 